\title{
Investigating Personality Traits as the Antecedents of Workplace Bullying
}

\author{
Dr. MUHAMMAD MUNIR \\ IPFP Fellow, Department of Management \& Administrative Sciences, \\ University of Narowal, Narowal. Pakistan. \\ Email: muhammad.munir@uon.edu.pk
}

\section{Dr. MAJID ALI}

Assistant Professor, Hailey College of Commerce, University of the Punjab, Lahore. Pakistan. Email: majid.hcc@pu.edu.pk

\section{Dr. SYED KARIM HAIDER}

Assistant Professor, Pakistan Study Centre, University of the Punjab, Lahore. Pakistan. Email: haider.psc@pu.edu.pk

\begin{abstract}
There is an ample body of knowledge showing significant association between five factor model (FFM) of personality traits and workplace bullying, yet exploring cause-and-effect relationship between them is still under addressed. To address this issue, current study has analyzed personality traits of Five-Factor Model as a potential antecedent of workplace bullying and its three sub-facets (verbal bullying, social bullying and physical bullying). Study analyzed responses of 266 respondents to draw inferences. Simple random sampling technique was used to collect data from the respondents. Correlation analysis showed a positive association of extraversion with physical bullying; negative association of agreeableness with workplace bullying, verbal bullying, social bullying and physical bullying; negative association of conscientiousness with workplace bullying, verbal bullying, social bullying and physical bullying; and negative association of emotional stability with physical bullying. Results of regression analysis showed significant effect of agreeableness, conscientiousness and openness to experiences on workplace bullying, verbal bullying, social bullying and physical bullying. Current study has identified personality as an important predictor of workplace bullying through which organizations may control incidence of bullying at their workplace environments. Current study also has highlighted important insights for future research directions.
\end{abstract}

Keywords: Five Factor Model (FFM), Personality Traits, Workplace Bullying, Physical Bullying, Verbal Bullying, Social Bullying.

\section{Introduction}

Healthy workplace environment in the organizations is a mandatory requirement for obtaining optimum output through their resources. However, stressors at workplace result in a decline in performance of its resources, especially human resources (Cowan, 2018; Hobfoll, Halbesleben, Neveu, \& Westman, 2018; Marinova, Cao, \& Park, 2018). Workplace bullying is an important workplace stressor that significantly but inversely affects healthy workplace environment, employee performance and organizational performance (Finchilescu, Bernstein, \& Chihambakwe, 2019; Munir, Attiq, \& Zafar, 2020). Workplace bullying 
includes all types of repeated consistent negative behaviors exhibited to harass, offend, retaliate, and isolate the victims (Einarsen, Hoel, Zapf, \& Cooper, 2011). It can be exhibited by any organizational member irrespective of hierarchical level (Glambek, Skogstad, \& Einarsen, 2018). But a single incident of such behavior cannot be considered and treated as workplace bullying (Carbo, 2017). However, a mere incident may result in actual happening of workplace bullying incidence. All negative acts cannot be regarded as workplace bullying except exhibited on weekly basis (Mikkelsen \& Einarsen, 2002) for a period of six months (Hoel, Cooper, \& Faragher, 2001) with real or perceived power disparity (Hodson, Roscigno, \& Lopez, 2006), and changing behavior of target (Einarsen, Hoel, \& Notelaers, 2009). By applying this criteria, one can differentiate workplace bullying incidents form mere negative acts. Hence, a careful examination of such potential preamble workplace bullying incidents becomes necessary. This situation also necessitates developing a clear understanding of phenomenon, types, antecedents, and consequences of workplace bullying incidence.

There are three major areas of workplace bullying antecedents including the bully/instigator, the target, and the situation (Bowling \& Beehr, 2006). However, further studies are needed to refine these factors (Kemp, 2014). There is also a need to explore and refine relationship between workplace bullying and personality (Clark, Barbosa-Leiker, Gill, \& Nguyen, 2015; Linton\& Power, 2013; Nielsen, Hetland, Matthiesen, \& Einarsen, 2012) due to the existing contradiction upon the nature of association between personality and workplace bullying (Nielsen, Glas $\varnothing$, \& Einarsen, 2017). Rai and Agarwal (2019) examined personality as an antecedent of bullying and recommended to further investigate the phenomenon by arriving at a more authentic conclusion. These calls to explore personality traits of parties involved in bullying, associating personality traits with bullying, and establishing a cause-and-effect relationship between personality and workplace bullying for developing theoretical models (Zapf \& Einarsen, 2003)and applied purposes (Nielsen et al., 2017; Pallesen, Nielsen, Magerøy, Andreassen, \& Einarsen, 2017)necessitate further research in this avenue. As there is consistent cross-cultural validation of five-factor model of personality (McCrae\& John, 1992), current study has used FFM of personality traits as suggested by Nielsen et al. (2017).

Current study has put its reliance on the explanatory mechanisms of personliaty traits provided by Nielsen and Knardahl (Nielsen\& Knardahl, 2015), and expanded by Nielsen. et al. (2017) while exploring possible association between FFM of peronality and workplace bullying. Current study has tried to validate or negate the associations found by Nielsen. et al. (2017) and further testified a hypothesized cause-and-effect relationship between them by using Five Factor Model (FFM) of personality traits and workplace bullying. Nielsen. et al.(2017) explored the potential association between personality and workplace bullying by using five-factor model of personality. They found significant associations of personality traits with workplace bullying incidence. However, one personality trait i.e. openness to experience was not significantly associated with workplace harassment. Moreover, Rai and Agarwal (2019) argued that scholars needed to probe personality traits as antecedents of bullying as it remained an inconclusive matter. These calls require further studies for testifying and validating such associations. Furthermore, they did not analyze cause-and-effect relationship between Five Factor Model (FFM) of personality traits and workplace bullying. Hence, validation of current findings and exploration of cause-and-effect relationship between personality and workplace bullying has become a research problem of an important avenue for future research.

After grasping the research problem, researchers formulated problem statement as, "how does Five Factor Model (FFM) of personality traits affect workplace bullying?" By putting reliance on the research gap available and framing research problem, current study tried to validate associations between personality traits and workplace bullying by using five-factor model of personality, explored personality traits as a potential antecedents of workplace bullying incidence, and evaluated effect of personality traits on subfacets of workplace bullying incidence. 


\section{Literature Review}

\section{Workplace Bullying}

According to Gredler (2003), phenomenon of bullying got attention of scholars in scientific literature in late 1970s. Intially, the prime focus of research was put on bullying among school children (Nielsen, Tangen, Idsoe, Matthiesen, \& Magerøy, 2015). Later on, scholars started to focus bullying among the adults with a special focus on bullying incidence happening at workplace (Nielsen, Indregard, \& Øverland, 2016). Workplace bullying includes a comprehensive set of negative behaviors exhibited repeatedly and regularly in which a target remains in lower power position and remain vulnerable to systematic process of workplace bullying. But, a conflict being an isolated incident, could not be termed as workplace bullying where target also has equal power (Einarsen, Hoel, \& Cooper, 2002). Previous literature has found four most important facets of workplace bullying as frequency, intensity, duration, and power disparity (Agervold, 2007). All negative acts that are exhibited once in a week (Mikkelsen \& Einarsen, 2002), endure for, at least, six months (Hoel et al.,2001), represent a real/perceived power disparity between perpetrator and the target (Hodson et al., 2006), and significantly change behavior of target (Einarsen et al., 2009) are included in the scope of workplace bullying. Workpalce bullying may be exhibited by any member of the organization irrespective of organizational hierarchy (Ariza-Montes, Muniz Leal-Rodríguez, \& Leal-Millán, 2014).

Workplace bullying has various negative effects on organizations and organizational members. Negative effects of workplace bullying on organizations include increased costs due to high rate of absenteeism, sick leave, payouts, counseling and rehiring (Speedy, 2006), increased costs of recruitment, selection, retaining, and retraining employees (Bartlett \& Bartlett, 2011), deterioration of healthy workplace environment (Schutte \& Loi, 2014), increased hiring costs (Einarsen \& Nielsen, 2015), non-achievement of organizational goals (Beach, 2007), increased training costs (Foster \& Scott, 2015), increased employee turnover and increased legal costs (McGee, 2016), and decreased productivity (Kwan, Tuckey, \& Dollard, 2016).

On the contrary, negative effects of workplace bullying on individual level include decreased innovation and creativity (Simpson \& Cohen, 2004), hostile physiological, psychological, organizational, clinical symptoms (Bowling \& Beehr, 2006), using drugs (Baker\& Pelfrey, 2016), lack cooperation (Agervold, 2007), experience health issues even committing suicide (Lutgen-Sandvik, Tracy, \& Alberts, 2007),decreased work productivity and performance (Clark et al., 2015), increased workplace errors (Baillien, Neyens, De Witte, \& De Cuyper, 2009), psychological stress resulting in suicide thoughts (Einarsen \& Nielsen, 2015), low productivity and creativity (Maiuro, 2015), and poor performance (Hansen \& Søndergaard, 2018; Munir et al., 2020).

There are various antecedents of workpalce bullying. However, there are three major sources of antecedents of workplace bullying incidence which include bully, victim, and work environment (Bowling \& Beehr, 2006). The most common antecedents of workplace bullying include contextual factors (Hershcovis et al., 2007), situational factors (Einarsen\& Nielsen, 2015), personality traits (Clark et al., 2015; Rai \& Agarwal, 2019). Major situational and contextual antecedents of workplace bullying include organizational injustice (Hershcovis et al., 2007), little job autonomy and job insecurity (Baillien, De Cuyper, \& De Witte, 2011), job monotony and workplace boredom (Bruursema, Kessler, \& Spector, 2011), autocratic leadership style (Valentine, Fleischman, \& Godkin, 2015), weak working relations (Francioli et al., 2016), and weak organizational culture (Kwan et al., 2016).

\section{Personality as an Antecedent of Workplace Bullying}

Although there are situational and contextual antecedents, this study has carried personality traits as an antecedent of workplace bullying (Clark et al., 2015) due to the fact that most of the organizational systems 
are centered on the personality traits. The workpalce bullying occurs when workplace environment has narcissist employees (Hauge et al., 2011) who have anger issues, vengeance and anxiety (Hershcovis et al., 2007), desire for vengeance (Ferris et al., 2011), and inferiority complex(Ferris, Spence, Brown, \& Heller, 2012). Sometimes perpetrator and the targets had similar personality traits (Vie, Glasø, \& Einarsen, 2010) but sometimes they differ significantly (Pallesen et al., 2017; Rai \& Agarwal, 2019). Hence, this study has discussed the conversation in the context of personality traits of bullies.

\section{Five Factor Model of Personality Traits and Workplace Bullying}

Most of the previous studies have used five-factor model of personality (FFM) while exploring personality as a potential antecedent of workplace bullying (Nielsen et al., 217; Rai \& Agarwal, 2019). The mechanisms of workplae bullying, being negative acts, can be explained with the explanation of five personality traits of extraversion, agreeblness, conscientiousness, emotional statbility and openness to experience (Nielsen \& Knardahl, 2015). In the inception of personality theory, Buss (1991) opposed the argumentation of Rorer and Widiger (1983) that personality theory has ruined the psychology model of physics. He rather proposed practical implications of personality traits as a solution to majority of pscychological problems. In line with this view, various studies have been conducted in almost all fields of psychology, behvioral sciences and social sciences. As five-factor model of personality interprets traits of all member, it has important implications while interacting in our social environment. As this view of personality traits also has importatnt implications on organizational itneractions, studying workplace bullying incidence in connection with personality traits has as an important organizational concern (Pallesen et al., 2017; Rai \& Agarwal, 2019).

The five factors of personlaity cosist of five personaity traits which include extraversion, extraversion, agreeableness, emotional stability or neuroticism, and openness to experience (McCrae \& John, 1992). These traits represents an individual's tendency to think, feel, and act in consistent ways. So, this model also explains possible wokplace interactions. For example, employees with neuroticism trait are generally avoided by others in order to keep themselves escaped from various consequent problems. Employees with extraversion generally engage in helping others in social situations and are percieved as friends. Seigne, Coyne, Randall, and Parker (2007) found an inverse accociation of agreeableness as a trait of bullies with bullying incidence. These findings were confirmed by Turner and Ireland (2010)who found an inverse accociation of agreeableness with bullying incidence. They also found a direct association of neuroticism with bullying incidence. These aggregated findings were also confirmed by a later meta-analysis of Mitsopoulou and Giovazolias (2015). They argued that previous studies had found significant relationship between personality traits and bullying incidence. They further apportioned their analysis by differentiating personality traits of bullies from personality traits of victims. They found a direct association of neuroticism and extraversion traits of bully (perpetrator) with their bullying behaviors. However, conscientiousness, agreeableness and openness to eperiene traits of bully had inverse association with their bullying behaviors. On the contrary, they found that neuroticism trait of victim was directly assoicated with being a target of bullying incidence.

\section{Extraversion and Bullying at Workplace}

Extraversion refers to the tendency of an individual to be social, talkative, excitement-oriented person (McCrae\& John, 1992), and positively emotional (Watson \& Clark, 1997). Employees with extraversion trait also enjoy spending more time in social interactions at workplace with a probable chance of rewards for them (Watson \& Clark, 1997). Nielsen and Knardahl (2015) explained a multifold relationship between extraversion and workplace bullying. They argued when extroverts needed attention of others and wanted to control the social environment at workplace, they had initiated bullying behaviors. They further added when the extroverts had found some reserved employees, they perceive them as unfriendly, cold, or uninvolved which had forced extroverts to target them. As the introvert employees became the targets of extrovert employees, introversion was also positively associated with workplace bullying. However, such 
targeting was perceived to be positive enforcement by the extroverts due to their positive emotions as an integral part of extraversion trait. In this way, the bullying incidence was occurred at workplace environment.

Studies have found some contradictory associations between extraversion and workplace bullying. Weber, Ziegele, and Schnauber (2013) found a positive whereas Nielsen et al. (2017) found a negative association between extraversion and workplace bullying. In a longitudinal experimental vignette study, Pallesen et al. (2017) found a significant positive association of workplace bullying incidence with extraversion. However, Rai \& Agarwal (2019) found a significant negative association between them. Therefore, validation of recent findings becomes essential to clarify this contradiction. In the light these stated findings, we proposed following hypothesis:

$\mathrm{H}_{1}$. There is a positive association between extraversion and workplace bullying.

\section{Agreeableness and Bullying at Workplace}

Agreeableness refers to refers to the tendency of an individual to be a likeable, understanding, and diplomatic person (Pervin \& John, 1999). People scoring high on agreeableness create positive effect in their social environment (McCrae \& Costa, 1991). On the contrary, people scoring low on agreeableness may initiate bullying in their social environment at workplace (Berry, Ones, \& Sackett, 2007). This might lead to lack of mutual trust in workplace setting that may also lead to the generation of workplace bullying incidence in the organizations. With respect to a comparison/contrast between low scoring and high scoring individuals, researchers have used reversed causality mechanism throughout this paper. Nielsen. et al. (2017) and Rai \& Agarwal (2019) found a significant negative association between them. They found negative association between agreeableness and workplace bullying. By summing the findings, researchers perceived a negative association of agreeableness with workplace bullying. Hence, the following was formulated for testing:

$\mathrm{H}_{2}$. There is a negative association between agreeableness and workplace bullying.

\section{Conscientiousness and Bullying at Workplace}

Conscientiousness refers to refers to the tendency of an individual to be an organized, controlled, persistent, motivated and goal-directed person (McCrae \& Costa, 1991). Pervin and John (1999) argued that people having personality trait of conscientiousness tended to be very organized and dependable. Previous literature found an inverse relationship between a bully's personality of conscientiousness and workplace bullying (Brodsky, 1976; Nielsen \& Knardahl, 2015).The negative association between conscientiousness and workplace bullying (Nielsen. et al., 2017)can be explained in a mechanism when a highly organized and goal directed employee irritates bully, workplace bullying incidence occurs. However, Rai \& Agarwal (2019)found a significant negative association between them. As a result, a target withdraws him/her from performing job duties in highly organized manner. Moreover, the target also decreases his level of conscientiousness as a result of workplace bullying (Nielsen \& Knardahl, 2015). Therefore, we had developed the following hypothesis:

$\mathrm{H}_{3}$. There is a negative association between conscientiousness and workplace bullying.

\section{Emotional Stability/ Neuroticism and Bullying at Workplace}

Emotional stability refers to the tendency of an individual to be more relaxed and stable whereas instability includes the tendencies of becoming emotionally instable, anxious and nervous (Pervin \& John, 1999). This personality trait is also represented by the term "neuroticism" which explains emotional stability and instability as two opposite characteristics. However, both the terms represent the trait in similar theme by 
two different ways. Neuroticism is positively associated with workplace bullying (Bowling, Beehr, Bennett, \& Watson, 2010). On the contrary, from target's perspective, employees scoring low becomes an easy target of workplace bullying (Nielsen \& Knardahl, 2015) when a bully identifies his target as emotionally instable. Rai \& Agarwal (2019) found a significant negative association between them. Therefore, we had proposed the following hypothesis for testing:

$\mathrm{H}_{4}$. There is a negative association between conscientiousness and workplace bullying.

\section{Openness to Experience and Bullying at Workplace}

Openness refers to the tendency of an individual to be involved in new activities, experiences, emotions, scientific or artistic creativity, divergent thinking, and political liberalism by taking keen interest in culture (Judge, Heller, \& Mount, 2002). People scoring high on this trait become very non-traditional due to wide variety of interests and avoid conventional outlook. Previous literature has found no significant relation of this personality trait with negative affectivity (Steel, Schmidt, \& Shultz, 2008). Negative affectivity includes experience of negative emotions including negative emotions of poor self-concept, fear, nervousness, anger, contempt, disgust, guilt (Brief, Burke, George, Robinson, \& Webster, 1988). Consequently, openness to experience should not be significantly associated with workplace bullying which is a type of negative affectivity (Mikkelsen \& Einarsen, 2002). Moreover, literature also concludes that openness to experience the least predictive trait of Big Five Factor Model of personality trait when it is studied in connection with negative consequences at workplace(Alarcon, Eschleman, \& Bowling, 2009; Berry et al., 2007). In opposition, Nielsen and Knardahl(2015) found a negative association between them. However, Nielsen et al. (2017) found no significant association of openness to experience with workplace bullying. In a longitudinal experimental vignette study, Pallesen et al. (2017) also found no significant association of openness to experience with workplace bullying incidence. However, Rai \& Agarwal (2019) found a significant negative association between them. Leading this conversation, we argue that as extroverts are involved in workplace bullying behaviors, it seems logical to check whether or not is there any significant association of openness to experience, which is closely related to extraversion trait, and workplace bullying. Therefore, the following hypothesis was framed:

$\mathrm{H}_{5}$. Openness to experience is positively associated with workplace bullying.

\section{Materials and Methods}

Current study chose utilized responses of 266 respondents as the sample size from a population of employees working in a leading private health care organization of Islamabad. This sample size was selected on the basis of "Sample Size Table for Given Population" for sample size determination provided by Krejcie and Morgan (1970). With regard to sampling technique, simple random sampling technique was used. Healthcare sector was selected to obtain target population due to the evidence that a higher reporting rate of workplace bullying incidence was found in health services industry than other sectors by the previous studies. Researchers used measurement scale of Gosling, Rentfrow, and Swann (2013) for measuring personality traits and NAQ-R - Negative Acts Questionnaire-Revised of Einarsen et al. (2009) for measuring workplace bullying incidence. Both the scales were used after getting permission from the copy right owners. Previous literature found a significant gender difference in bullying incidence (Namie \& Namie, 2018), inverse association of age with bullying (Alterman, Luckhaupt, Dahlhamer, Ward, \& Calvert, 2013; Mitsopoulou \& Giovazolias, 2015), difference in bullying incidence for divorced or separated and other marital statuses of workers (Alterman et al., 2013), and an inverse association between education and bullying (Alterman et al., 2013). This suggested to include these variables as control variables in current study. However, current study only used gender as control variable on the basis of significant association between gender and workplace bullying found in ANOVA analysis. 


\section{Results}

\section{Demographic Information}

The following table presents demographic information of 266 respondents:

Table 1: Demography of Respondents

\begin{tabular}{|c|c|c|c|c|c|c|c|c|c|}
\hline Gender & Frequency & $\begin{array}{l}\text { Marital } \\
\text { Status }\end{array}$ & Frequency & $\begin{array}{l}\text { Age } \\
\text { Group }\end{array}$ & Frequency & Education & Frequency & $\begin{array}{l}\text { Work } \\
\text { Experience }\end{array}$ & Frequency \\
\hline Male & 198 & Unmarried & 64 & $18-25$ & 22 & Matric & 3 & $<1$ Year & 31 \\
\hline \multirow[t]{4}{*}{ Female } & 68 & Married & 155 & $26-35$ & 87 & $\begin{array}{l}\text { Intermedia } \\
\mathrm{e}\end{array}$ & $\mathrm{t} 21$ & $1-5$ & 88 \\
\hline & & Separated & 2 & $36-45$ & 50 & Bachelors & 74 & $6-10$ & 103 \\
\hline & & $\begin{array}{l}\text { Didn't } \\
\text { Answer }\end{array}$ & 47 & 46 or $>$ & 6 & Masters & 153 & 11 or $>$ & 44 \\
\hline & & & & $\begin{array}{l}\text { Didn't } \\
\text { Answer }\end{array}$ & 101 & $\begin{array}{l}\text { MS/ } \\
\text { M.Phil/ } \\
\text { PhD }\end{array}$ & 15 & & \\
\hline Total & 266 & & 266 & 266 & 266 & 266 & 266 & 266 & 266 \\
\hline
\end{tabular}

\section{Correlation Analysis}

Researchers checked basic assumptions of data including normality and multi-collinearity before running regression analysis. The following results pertain to these assumptions:

Table 2: Correlations

\begin{tabular}{|c|c|c|c|c|c|}
\hline Variables & & Bullying & V. Bullying & S. Bullying & P. Bullying \\
\hline \multirow{2}{*}{ EXT } & Pearson Correlation & .015 & .012 & .043 & $.160^{*}$ \\
\hline & Sig. (2-tailed) & .843 & .866 & .578 & .033 \\
\hline \multirow{2}{*}{ AGR } & Pearson Correlation & $-.276 * *$ & $-.313 * *$ & -.060 & $-.247 * *$ \\
\hline & Sig. (2-tailed) & .000 & .000 & .373 & .000 \\
\hline \multirow{2}{*}{ CONS } & Pearson Correlation & $-.213 * *$ & $-.272 * *$ & $-.207 * *$ & $-.276 * *$ \\
\hline & Sig. (2-tailed) & .001 & .000 & .002 & .000 \\
\hline \multirow{2}{*}{ ES } & Pearson Correlation & -.111 & -.094 & -.023 & $-.226 * *$ \\
\hline & Sig. (2-tailed) & .070 & .137 & .727 & .000 \\
\hline \multirow{2}{*}{$\mathrm{OE}$} & Pearson Correlation & .083 & .109 & .038 & .062 \\
\hline & Sig. (2-tailed) & .186 & .089 & .579 & .344 \\
\hline
\end{tabular}

Correlation analysis showed a positive association of extraversion with physical bullying $(\mathrm{r}=.160, \mathrm{p}=$ .033). However, it had no significant correlation with bullying and sub-facets of verbal bullying and social bullying. There was a negative association of agreeableness with workplace bullying $(r=-.276, p=.000)$, verbal bullying $(\mathrm{r}=-.313 \mathrm{p}=.000)$, social bullying $(\mathrm{r}=-.060, \mathrm{p}=.373)$ and physical bullying $(\mathrm{r}=-.247, \mathrm{p}$ $=.000)$. There was negative association of conscientiousness with workplace bullying $(\mathrm{r}=-.213, \mathrm{p}=.001)$, verbal bullying $(\mathrm{r}=-.272, \mathrm{p}=.000)$, social bullying $(\mathrm{r}=-.207, \mathrm{p}=.000)$ and physical bullying $(\mathrm{r}=-.276, \mathrm{p}$ $=.000)$. There was negative association of emotional stability with physical bullying $(\mathrm{r}=-.226, \mathrm{p}=.000)$ whereas it had no significant correlation with bullying and sub-facets of verbal bullying and social bullying. The correlation of personality trait of openness to experience was not significant with bullying and three sub-facets of bullying. Researchers relied on 0.05 and 0.01 levels of significance for correlation analysis. 


\section{Normality Analysis}

Researchers checked basic assumptions of data including normality and multi-collinearity before running regression analysis. The following results pertain to these assumptions:

Table 3: Skewness and Kurtosis

\begin{tabular}{|c|c|c|c|c|c|c|}
\hline \multirow{2}{*}{ Variables } & \multirow[t]{2}{*}{ Skewness } & \multirow{2}{*}{$\begin{array}{l}\text { Std. Error } \\
\text { of Skewness }\end{array}$} & \multirow[t]{2}{*}{ Kurtosis } & \multirow{2}{*}{$\begin{array}{l}\text { Std. Error of } \\
\text { Kurtosis }\end{array}$} & \multicolumn{2}{|c|}{ t-statistics } \\
\hline & & & & & Skewness & Kurtosis \\
\hline Bullying & 0.333 & 0.214 & -0.011 & 0.298 & 1.556 & -0.036 \\
\hline Extraversion & 0.695 & 0.352 & 0.324 & 0.352 & 1.974 & 0.920 \\
\hline Agreeableness & -0.054 & 0.151 & -0.340 & 0.300 & -0.357 & -1.133 \\
\hline Consciousness & 0.322 & 0.187 & 0.316 & 0.300 & 1.721 & 1.053 \\
\hline Emotional Stability & -0.338 & 0.197 & 0.785 & 0.410 & -1.715 & 1.914 \\
\hline Openness to Experience & -0.659 & 0.331 & 1.370 & 0.712 & -1.990 & 1.924 \\
\hline
\end{tabular}

The results of skewness and kurtosis analysis showed that data set was normally distributed with respect to all variables because t-statistics of skewness and kurtosis were falling between the normal ranges of +1.96 and -1.96 .

Table 4: Collinearity Diagnostic

\begin{tabular}{|llll|}
\hline \multicolumn{4}{c|}{ Table 4: Collinearity Diagnostic } \\
\cline { 3 - 4 } & & \multicolumn{2}{l|}{ Collinearity Statistics } \\
\cline { 2 - 4 } & & Tolerance & VIF \\
\hline \multirow{3}{*}{1} & Extraversion & .988 & 1.012 \\
& Agreeableness & .682 & 1.467 \\
& Consciousness & .758 & 1.319 \\
& Emotional Stability & .669 & 1.495 \\
& Openness to Experience & .704 & 1.421 \\
\hline
\end{tabular}

Collinearity diagnostic test was run to check multi-collinearity in the data set as required by the regression analysis. Variance inflation factors (VIFs) lesser than 4 for all independent variables showed that there was no problem of multicollinearity which could distort reliability of significance test and findings (Johnston, Jones, \& Manley, 2018).

\section{Regression Analysis}

After complying with the assumptions, regression analysis was run for model 1,2,3 and 4 respectively. Model 1 included workplace bullying as dependent variable, Model 2 included verbal bullying as dependent variable, Model 3 included social bullying as dependent variable and Model 4 included physical bullying as dependent variable.

Table 5: Model Summary

\begin{tabular}{|lllll|}
\hline Model & R & R Square & Adjusted R Square & Std. Error of the Estimate \\
\hline 1 & .494 & .244 & .222 & .24927 \\
2 & .480 & .231 & .208 & .46768 \\
3 & .295 & .087 & .059 & .45200 \\
4 & .558 & .311 & .290 & .68114 \\
\hline \multicolumn{4}{l}{ Predictors: (Constant), EXT, AGR, CONS, ES, OE } \\
\hline
\end{tabular}

In model 1 , the value of adjusted $r$-square (0.222) showed $22.2 \%$ variation in workplace bullying incidence that was caused due to one unit change in personality traits including extraversion, agreeableness, 
consciousness, emotional stability and openness to experience. In model 2, the value of adjusted r-square (0.208) showed $20.8 \%$ variation in verbal bullying that was caused due to one unit change in personality traits including extraversion, agreeableness, consciousness, emotional stability and openness to experience. In model 3, the value of adjusted r-square (0.059) showed only 5.9\% variation in social bullying that was caused due to one unit change in personality traits including extraversion, agreeableness, consciousness, emotional stability and openness to experience. In model 4, the value of adjusted r-square (0.290) showed $29 \%$ variation in physical bullying that was caused due to one unit change in personality traits including extraversion, agreeableness, consciousness, emotional stability and openness to experience.

Table 6: ANOVA

\begin{tabular}{|lllllll|}
\hline Model & & Sum of Squares & df & Mean Square & F & Sig. \\
\hline \multirow{4}{*}{1} & Regression & 3.485 & 5 & .697 & 11.219 & $.000 \mathrm{~b}$ \\
& Residual & 10.811 & 174 & .062 & & \\
& Total & 14.297 & 179 & & & \\
\hline \multirow{2}{*}{2} & Regression & 11.407 & 5 & 2.281 & 10.431 & $.000 \mathrm{~b}$ \\
& Residual & 38.059 & 174 & .219 & & \\
& Total & 49.466 & 179 & & & \\
\hline \multirow{7}{*}{3} & Regression & 3.185 & 5 & .637 & 3.118 & $.010 \mathrm{~b}$ \\
& Residual & 33.302 & 163 & .204 & & \\
& Total & 36.487 & 168 & & & $.000 \mathrm{~b}$ \\
4 & Regression & 33.983 & 5 & 6.797 & & \\
& Residual & 75.160 & 162 & .464 & & \\
\hline & Total & 109.143 & 167 & & \\
Dependent Predictors: (Constant), EXT, AGREEAB, CONS, ES, OE
\end{tabular}

In all models, significance value was lesser than 0.05 which showed that the models were statistically significant. Hence, researchers rejected null hypothesis that personality traits (extraversion, agreeableness, consciousness, emotional stability and openness to experience) had no significant impact on bullying and its sub-facets including verbal bullying, social bullying and physical bullying. These cause and effect relationships were further confirmed by standard beta coefficients given in the following table:

Table 7: Coefficients ${ }^{\mathrm{a}}$

\begin{tabular}{|c|c|c|c|c|}
\hline Model & & $\begin{array}{l}\text { Standardized } \\
\text { Coefficients } \\
\text { Beta }\end{array}$ & $\mathrm{t}$ & Sig. \\
\hline \multirow{6}{*}{1} & (Constant) & & 11.641 & .000 \\
\hline & Extraversion & .062 & .942 & .348 \\
\hline & Agreeableness & -.427 & -5.342 & .000 \\
\hline & Consciousness & -.145 & -1.908 & .058 \\
\hline & Emotional Stability & .042 & .525 & .600 \\
\hline & Openness to Experience & .182 & 2.310 & .022 \\
\hline \multirow{6}{*}{2} & (Constant) & & 7.706 & .000 \\
\hline & Extraversion & .015 & .227 & .821 \\
\hline & Agreeableness & -.361 & -4.480 & .000 \\
\hline & Consciousness & -.244 & -3.195 & .002 \\
\hline & Emotional Stability & .126 & 1.545 & .124 \\
\hline & Openness to Experience & .181 & 2.278 & .024 \\
\hline
\end{tabular}




\begin{tabular}{|c|c|c|c|c|}
\hline \multirow{3}{*}{3} & (Constant) & & 7.539 & .000 \\
\hline & Extraversion & .117 & 1.556 & .122 \\
\hline & Agreeableness & -.038 & -.416 & .678 \\
\hline \multirow[t]{3}{*}{ Consciousness } & -.247 & -2.909 & .004 & \\
\hline & Emotional Stability & -.038 & -.398 & .691 \\
\hline & Openness to Experience & -.016 & -.176 & .861 \\
\hline \multirow{6}{*}{4} & (Constant) & & 8.210 & .000 \\
\hline & Extraversion & .246 & 3.741 & .000 \\
\hline & Agreeableness & -.186 & -2.324 & .021 \\
\hline & Consciousness & -.213 & -2.790 & .006 \\
\hline & Emotional Stability & -.317 & -3.997 & .000 \\
\hline & Openness to Experience & -.130 & -1.677 & .095 \\
\hline
\end{tabular}

In model 1, agreeableness and consciousness had inverse effect on workplace bullying incidence whereas this effect was positive for openness to experience. This effect was also confirmed by the respective tvalues which were at least near to an absolute number 2 . Other personality traits of this model had no significant effect on workplace bullying incidence. In model 2, agreeableness and consciousness had inverse effect on verbal bullying as a sub-facet of workplace bullying whereas this effect was positive for openness to experience. This effect was also confirmed by the respective t-values which were more than absolute value of 2 . Whereas extraversion and emotional stability had no significant effect on verbal bullying.

In model 3, only consciousness had inverse effect on social bullying which was also confirmed by the respective t-value -2.909 which was more than absolute value of 2 . Whereas other personality traits (extraversion, agreeableness, emotional stability and openness to experience) had no significant effect on verbal bullying. In model 4, agreeableness, consciousness, emotional stability and openness to experience had inverse effect on physical bullying. However, extraversion had positive effect on physical bullying. These effects were also confirmed by their respective absolute $t$-values which were more than 2 . In this model, openness to experience had no significant effect on physical bullying. Hence, hypothesis developed by this study was rejected.

\section{Discussions}

Findings of this study showed a significant association between five factor model (FFM) of personality traits and workplace bullying. This study also found that cause-and-effect relationship between them also existed. Findings revealed a positive association of extraversion with workplace bullying similar to the findings of Pallesen et al. (2017).

The negative associations of agreeableness, conscientiousness, and emotional stability along with no significant association of openness to experiences with workplace bullying were similar to the findings of Nielsen. et al. (2017).In terms of cause-and-effect relationship, findings of this study revealed a significant negative effect of agreeableness and consciousness on workplace bullying incidence. On the contrary, a significant positive effect of openness to experience on workplace bullying incidence was found. However, no significant effect was found with respect to extraversion and emotional stability (neuroticism).

From the above stated findings, researchers conclude that personality traits significantly affect workplace bullying incidence. The traits of agreeableness and consciousness inversely effect workplace bullying incidence and verbal bullying; openness to experience positively affect verbal bullying; consciousness inversely affect social bullying; agreeableness, consciousness, emotional stability and openness to 
experience inversely affect physical bullying; and extraversion positively affect physical bullying. Current study has added critical aspects in the area of personality traits and workplace bullying by filling the research gaps left unfilled by the previous studies.

\section{Recommendations}

Findings of this study help managers to understand personality traits and, consequently, diagnose potential bullies at workplace. It would help them in making their organizations proactive to counter bullying phenomenon which results in non-achievement of organizational goals(Beach, 2015). Findings also guide practitioners to effectively develop anti-bullying interventions for bullies by analyzing their personality traits as desired by Seigne et al. (2007). Those interventions may be aimed at targeting policy level (Vartia, Lahtinen, Joki, \& Soini, 2008), organizational level (Rayner \& Lewis, 2011), and/or group level or individual level (Giga, Hoel, \& Lewis, 2008). A careful analysis of personality traits of bullies would lead practitioners to incorporate appropriate psychological interventions which are more effective in reducing their exhibition of such negative acts. Moreover, it becomes an easy task for managers to find motivational factors which instigate or counter bullies from their negative acts at workplace environment.

This study also carries some limitations which may prove opportunities future research in the field. Current study has used analysis of personality traits relating to the bullies in the incidence of workplace bullying. However, the development of counseling and therapeutic interventions also requires an in-depth analysis of personality traits of targets (Salin, Tenhiälä, Roberge, \& Berdahl, 2014).Hence, we recommend future studies to probe in this complementary direction in order to develop comprehensive anti-bullying interventions to counter workplace bullying phenomenon. We have developed a causal relationship of agreeableness, consciousness, and openness to experience with workplace bullying which needs to be confirmed by the future studies by using experimental design with longitudinal data sets.

\section{References}

Agervold, M. (2007). Bullying at work: A discussion of definitions and prevalence, based on an empirical study. Scandinavian journal of psychology, 48(2), 161-172.

Alarcon, G., Eschleman, K. J., \& Bowling, N. A. (2009). Relationships between personality variables and burnout: A meta-analysis. Work \& Stress, 23(3), 244-263.

Alterman, T., Luckhaupt, S. E., Dahlhamer, J. M., Ward, B. W., \& Calvert, G. M. (2013). Job insecurity, work-family imbalance, and hostile work environment: Prevalence data from the 2010 National Health Interview Survey. American Journal of Industrial Medicine, 56(6), 660-669.

Ariza-Montes, J. A., Muniz R, N. M., Leal-Rodríguez, A. L., \& Leal-Millán, A. G. (2014). Workplace bullying among managers: A multifactorial perspective and understanding. International Journal of Environmental Research and Public Health, 11(3), 2657-2682.

Baillien, E., De Cuyper, N., \& De Witte, H. (2011). Job autonomy and workload as antecedents of workplace bullying: A two-wave test of Karasek's Job Demand Control Model for targets and perpetrators. Journal of occupational and Organizational Psychology, 84(1), 191-208.

Baillien, E., Neyens, I., De Witte, H., \& De Cuyper, N. (2009). A qualitative study on the development of workplace bullying: Towards a three way model. Journal of Community \& Applied Social Psychology, 19(1), 1-16.

Baker, T., \& Pelfrey Jr, W. V. (2016). Bullying victimization, social network usage, and delinquent coping in a sample of urban youth: Examining the predictions of general strain theory. Violence and victims, 31(6), 1021-1043.

Bartlett, J. E., \& Bartlett, M. E. (2011). Workplace bullying: An integrative literature review. Advances in Developing Human Resources, 13(1), 69-84.

Beach, L. R. (2007). The human element: Understanding and managing employee behavior. ME Sharpe. Routledge 
Berry, C. M., Ones, D. S., \& Sackett, P. R. (2007). Interpersonal deviance, organizational deviance, and their common correlates: A review and meta-analysis. Journal of Applied Psychology, 92(2), 410.

Bowling, N. A., \& Beehr, T. A. (2006). Workplace harassment from the victim's perspective: a theoretical model and meta-analysis. Journal of applied psychology, 91(5), 998-1012.

Bowling, N. A., Beehr, T. A., Bennett, M. M., \& Watson, C. P. (2010). Target personality and workplace victimization: A prospective analysis. Work \& Stress, 24(2), 140-158.

Brief, A. P., Burke, M. J., George, J. M., Robinson, B. S., \& Webster, J. (1988). Should negative affectivity remain an unmeasured variable in the study of job stress? Journal of Applied Psychology, 73(2), 193-198.

Brodsky, C. M. (1976). The harassed worker. DC Heath \& Co.

Bruursema, K., Kessler, S. R., \& Spector, P. E. (2011). Bored employees misbehaving: The relationship between boredom and counterproductive work behaviour. Work \& Stress, 25(2), 93-107.

Buss, D. M. (1991). Evolutionary personality psychology. Annual Review of Psychology, 42(1), 459-491.

Carbo, J. A. (2017). Understanding, defining and eliminating workplace bullying: Assuring dignity at work. Taylor \& Francis.

Clark, C. M., Barbosa-Leiker, C., Gill, L. M., \& Nguyen, D. (2015). Revision and psychometric testing of the incivility in nursing education (INE) survey: introducing the INE-R. Journal of Nursing Education, 54(6), 306-315.

Cowan, R. L. (2018). When workplace bullying and mobbing occur: The impact on organizations. Workplace Bullying and Mobbing in the United States 2 Volume.

Einarsen, S., \& Nielsen, M. B. (2015). Workplace bullying as an antecedent of mental health problems: a five-year prospective and representative study. International archives of occupational and environmental health, 88(2), 131-142.

Einarsen, S., Hoel, H., \& Cooper, C. (Eds.). (2002). Bullying and emotional abuse in the workplace: International perspectives in research and practice. $\mathrm{CRC}$ press.

Einarsen, S., Hoel, H., \& Notelaers, G. (2009). Measuring exposure to bullying and harassment at work: Validity, factor structure and psychometric properties of the Negative Acts QuestionnaireRevised. Work \& stress, 23(1), 24-44.

Einarsen, S., Hoel, H., Zapf, D., \& Cooper, C. L. (2011). The concept of bullying and harassment at work: The European tradition. Bullying and harassment in the workplace: Developments in theory, research, and practice, 2, 3-40.

Ferris, D. L., Rosen, C. R., Johnson, R. E., Brown, D. J., Risavy, S. D., \& Heller, D. (2011). Approach or avoidance (or both?): Integrating core self-evaluations within an approach/avoidance framework. Personnel Psychology, 64(1), 137-161.

Ferris, D. L., Spence, J. R., Brown, D. J., \& Heller, D. (2012). Interpersonal injustice and workplace deviance: The role of esteem threat. Journal of Management, 38(6), 1788-1811.

Finchilescu, G., Bernstein, C., \& Chihambakwe, D. (2019). The impact of workplace bullying in the Zimbabwean nursing environment: is social support a beneficial resource in the bullying-well-being relationship? South African journal of psychology, 49(1), 83-96.

Foster, D., \& Scott, P. (2015). Nobody's responsibility: the precarious position of disabled employees in the UK workplace. Industrial Relations Journal, 46(4), 328-343.

Francioli, L., Høgh, A., Conway, P. M., Costa, G., Karasek, R., \& Hansen, Å. M. (2016). Do personal dispositions affect the relationship between psychosocial working conditions and workplace bullying?. Ethics \& Behavior, 26(6), 451-469.

Giga, S. I., Hoel, H., \& Lewis, D. (2008). The costs of workplace bullying. University of Manchester Institute of Science and Technology 61-76.

Glambek, M., Skogstad, A., \& Einarsen, S. (2018). Workplace bullying, the development of job insecurity and the role of laissez-faire leadership: A two-wave moderated mediation study. Work \& Stress, 32(3), 297-312.

Gosling, S., Rentfrow, P., \& Swann, W. (2013). Ten Item Personality Measure (TIPI)', Measurement Instrument Database for the Social Science. 
Gredler, G. R. (2003). Olweus, D.(1993). Bullying at school: What we know and what we can do. Malden, MA: Blackwell Publishing, 140 pp., \$25.00. Psychology in the Schools, 40(6), 699-700.

Hansen, H. R., \& Søndergaard, D. M. (2018). Bullying: A socially enacted phenomenon with individual effects. Nordic Studies in Education, 1-25.

Hauge, L. J., Einarsen, S., Knardahl, S., Lau, B., Notelaers, G., \& Skogstad, A. (2011). Leadership and role stressors as departmental level predictors of workplace bullying. International Journal of Stress Management, 18(4), 305.

Hershcovis, M. S., Turner, N., Barling, J., Arnold, K. A., Dupré, K. E., Inness, M., ... \& Sivanathan, N. (2007). Predicting workplace aggression: a meta-analysis. Journal of applied Psychology, 92(1), 228238.

Hobfoll, S. E., Halbesleben, J., Neveu, J. P., \& Westman, M. (2018). Conservation of resources in the organizational context: The reality of resources and their consequences. Annual Review of Organizational Psychology and Organizational Behavior, 5, 103-128.

Hodson, R., Roscigno, V. J., \& Lopez, S. H. (2006). Chaos and the abuse of power: Workplace bullying in organizational and interactional context. Work and occupations, 33(4), 382-416.

Hoel, H., Cooper, C. L., \& Faragher, B. (2001). The experience of bullying in Great Britain: The impact of organizational status. European journal of work and organizational psychology, 10(4), 443-465.

Johnston, R., Jones, K., \& Manley, D. (2018). Confounding and collinearity in regression analysis: a cautionary tale and an alternative procedure, illustrated by studies of British voting behaviour. Quality \& Quantity, 52(4), 1957-1976.

Judge, T. A., Heller, D., \& Mount, M. K. (2002). Five-factor model of personality and job satisfaction: A meta-analysis. Journal of Applied Psychology, 87(3), 530-541.

Kemp, T. (2014). Industrialisation in the non-western world. Routledge.

Krejcie, R. V., \& Morgan, D. W. (1970). Determining sample size for research activities. Educational and Psychological Measurement, 30(3), 607-610.

Kwan, S. S. M., Tuckey, M. R., \& Dollard, M. F. (2016). The role of the psychosocial safety climate in coping with workplace bullying: A grounded theory and sequential tree analysis. European Journal of Work and Organizational Psychology, 25(1), 133-148.

Linton, D. K., \& Power, J. L. (2013). The personality traits of workplace bullies are often shared by their victims: Is there a dark side to victims?. Personality and individual differences, 54(6), 738-743.

Lutgen-Sandvik, P., Tracy, S. J., \& Alberts, J. K. (2007). Burned by bullying in the American workplace: Prevalence, perception, degree and impact. Journal of Management Studies, 44(6), 837-862.

Maiuro, R. (Ed.). (2015). Perspectives on Bullying: Research on Childhood, Workplace, and Cyberbullying. Springer Publishing Company.

Marinova, S. V., Cao, X., \& Park, H. (2018). Constructive organizational values climate and organizational citizenship behaviors: A configural view. Journal of Management. Retrieved from http://journals. sagepub. com/doi/full/http://dx. doi. org/10.1177/0149206318755301.

McCrae, R. R., \& Costa Jr, P. T. (1991). Adding Liebe und Arbeit: The full five-factor model and wellbeing. Personality and Social Psychology Bulletin, 17(2), 227-232.

McCrae, R. R., \& John, O. P. (1992). An introduction to the five-factor model and its applications. Journal of personality, 60(2), 175-215.

McGee, J. A., \& Byington, J. R. (2016). M\&A due diligence: consideration of fraudulent financial statements. Journal of Corporate Accounting \& Finance, 27(2), 17-21.

Mikkelsen, E. G. E., \& Einarsen, S. (2002). Basic assumptions and symptoms of post-traumatic stress among victims of bullying at work. European journal of work and organizational psychology, 11(1), 87-111.

Mitsopoulou, E., \& Giovazolias, T. (2015). Personality traits, empathy and bullying behavior: A metaanalytic approach. Aggression and Violent Behavior, 21(2015), 61-72.

Munir, M., Attiq, S., \& Zafar, M. Z. (2020). Can incidence of workplace bullying really be reduced? Application of the transtheoretical model as tertiary stage anti-bullying intervention. Pakistan Business Review, 21(1), 762-777.

Namie, G., \& Namie, R. (2018a). Risk Factors for Becoming a Target of Workplace Bullying and 
Mobbing. Workplace Bullying and Mobbing in the United States. In M. Duffy \& D. C. Yamada (Eds.), Workplace Bullying and Mobbing in the United States. Santa Barbara, CA: Praeger/ABCCLIO.

Nielsen, M. B., \& Knardahl, S. (2015). Is workplace bullying related to the personality traits of victims? A two-year prospective study. Work \& Stress, 29(2), 128-149.

Nielsen, M. B., Glasø, L., \& Einarsen, S. (2017). Exposure to workplace harassment and the Five Factor Model of personality: A meta-analysis. Personality and individual differences, 104(2017), 195-206.

Nielsen, M. B., Hetland, J., Matthiesen, S. B., \& Einarsen, S. (2012). Longitudinal relationships between workplace bullying and psychological distress. Scandinavian journal of work, environment \& health, 38(1), 38-46.

Nielsen, M. B., Indregard, A. M. R., \& Øverland, S. (2016). Workplace bullying and sickness absence: a systematic review and meta-analysis of the research literature. Scandinavian journal of work, environment \& health, 42(5), 359-370.

Nielsen, M. B., Tangen, T., Idsoe, T., Matthiesen, S. B., \& Magerøy, N. (2015). Post-traumatic stress disorder as a consequence of bullying at work and at school. A literature review and metaanalysis. Aggression and violent behavior, 21(2015), 17-24.

Pallesen, S., Nielsen, M. B., Magerøy, N., Andreassen, C. S., \& Einarsen, S. (2017). An experimental study on the attribution of personality traits to bullies and targets in a workplace setting. Frontiers in psychology, 8(1045), 1-7.

Pervin, L. A., \& John, O. P. (1999). Handbook of personality: Theory and research: Elsevier.

Rai, A., \& Agarwal, U. A. (2019). Examining the Relationship Between Personality Traits and Exposure to Workplace Bullying. Global Business Review, 20(4), 1069-1087.

Rayner, C., \& Lewis, D. (2011). Managing Workplace Bullying: The Role of Policies. . In H. H. S. Einarsen, D. Zapf \& C. Cooper (Ed.), Bullying and harassment in the workplace: Developments in theory, research, and practice (pp. 327-340).

Rorer, L. G., \& Widiger, T. A. (1983). Personality structure and assessment. Annual Review of Psychology, 34(1), 431-463.

Salin, D., Tenhiälä, A., Roberge, M. É., \& Berdahl, J. L. (2014). 'I wish I had. : Target reflections on responses to workplace mistreatment. Human Relations, 67(10), 1189-1211.

Schutte, N. S., \& Loi, N. M. (2014). Connections between emotional intelligence and workplace flourishing. Personality and Individual Differences, 66(2014), 134-139.

Seigne, E., Coyne, I., Randall, P., \& Parker, J. (2007). Personality traits of bullies as a contributory factor in workplace bullying: An exploratory study. International Journal of Organization Theory \& Behavior, 10(1), 118-132.

Simpson, R., \& Cohen, C. (2004). Dangerous work: The gendered nature of bullying in the context of higher education. Gender, Work \& Organization, 11(2), 163-186.

Speedy, S. (2006). Workplace violence: the dark side of organisational life. Contemporary Nurse, 21(2), 239-250.

Steel, P., Schmidt, J., \& Shultz, J. (2008). Refining the relationship between personality and subjective well-being. Psychological Bulletin, 134(1), 138.

Turner, P., \& Ireland, J. L. (2010). Do personality characteristics and beliefs predict intra-group bullying between prisoners? Aggressive Behavior, 36(4), 261-270.

Valentine, S., Fleischman, G., \& Godkin, L. (2015). Rogues in the ranks of selling organizations: Using corporate ethics to manage workplace bullying and job satisfaction. Journal of Personal Selling \& Sales Management, 35(2), 143-163.

Vartia, M., Lahtinen, M., Joki, M., \& Soini, S. (2008). Piinan loppu: kiusaamistilanteiden selvittely työpaikalla (Stop the torment. Investigation and settling of bullying cases at the workplace). : Helsinki: Työterveyslaitos (Finnish Institute of Occupational Health).

Vie, T. L., Glas $\varnothing$, L., \& Einarsen, S. (2010). Does trait anger, trait anxiety or organisational position moderate the relationship between exposure to negative acts and self-labelling as a victim of workplace bullying? Nordic Psychology, 62(3), 67. 
Watson, D., \& Clark, L. A. (1997). Extraversion and its positive emotional core Handbook of personality psychology (pp. 767-793): Elsevier.

Weber, M., Ziegele, M., \& Schnauber, A. (2013). Blaming the victim: the effects of extraversion and information disclosure on guilt attributions in cyberbullying. Cyberpsychology, Behavior, and Social Networking, 16(4), 254-259.
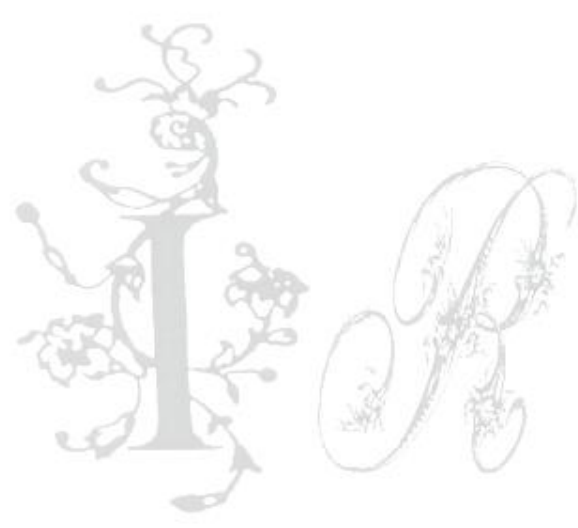